\title{
PERCEPTIONS OF STUDENTS OF THE FACULTY OF AGRICULTURE ON THE SOCIAL STATUS AND CAREER PROSPECTS IN THE AGRICULTURAL SECTOR
}

\author{
Yasinta Zulaikha ${ }^{1}$, Edhi Martono ${ }^{2}$ dan Fathul Himam ${ }^{3}$ \\ ${ }^{1}$ National Resilience Study Program, Graduate School, Universitas Gadjah Mada, Indonesia \\ ${ }^{2}$ Agriculture Faculty, Universitas Gadjah Mada, Indonesia \\ ${ }^{3}$ Psychology Faculty, Universitas Gadjah Mada, Indonesia \\ Correspondence Email: yasintazulaikha@gmail.com
}

Submitted 05 October 2019; Accepted 25 October 2020

\begin{abstract}
ABSTRAK
Fenomena semakin menurunnya minat tenaga kerja muda bekerja di sektor pertanian mempunyai konsekuensi bagi keberlanjutan sektor pertanian ke depan. Di masa depan beban sektor pertanian akan semakin berat dengan bertambahnya jumlah penduduk dan meningkatnya permintaan pangan. Krisis petani muda di sektor pertanian dan dominannya petani tua memiliki konsekuensi terhadap pembangunan sektor pertanian berkelanjutan, khususnya terhadap produktivitas pertanian, daya saing pasar, kapasitas ekonomi perdesaan, dan lebih lanjut hal itu akan mengancam ketahanan pangan serta keberlanjutan sektor pertanian. Penelitian ini bertujuan untuk mengetahui secara empiris pengaruh status sosial terhadap prospek karir di sektor pertanian. Penelitian ini melibatkan 110 responden dengan instrumen penelitian berupa kuisioner. Jenis penelitian yang digunakan dalam penelitian ini adalah jenis penelitian survey, yaitu jenis penelitian yang cara pengumpulan datanya didapatkan atau dikumpulkan dari sampel atau populasi yang diteliti. Pengujian dilakukan dengan uji regresi untuk mengetahui pengaruh status sosial terhadap prospek karir bidang pertanian. Hasil penelitian ini menunjukkan terdapat pengaruh yang signifikan antara status social sektor pertanian erhadap persepsi prospek karir di sektor pertanian. Karakteristik pekerjaan dan status sosial sektor pertanian saat ini secara umum dipersepsikan buruk yang mempengaruhi prospek karir sektor pertanian, sehingga ini menjadi tantangan bagi stakeholder untuk mengembangkan sektor pertanian dan pangan.
\end{abstract}

Kata kunci: karir, status sosial, pemuda, pertanian

\begin{abstract}
The phenomenon of the declining interest of young workers working in the agricultural sector has consequences for the sustainability of the agricultural sector going forward. In the future, the burden on the agriculture sector will be heavier with the increasing population and increasing food demand. The reasons for the decline in the interest of young workers works at agricultural sector are mainly caused by the image of the agricultural sector which is less prestigious and can not provide adequate rewards. The crisis of young farmers in the agricultural sector and the predominance of older farmers has consequences for the agriculture sector development, particularly on agricultural productivity, market competitiveness, ruraleconomic capacity, and further it will threaten food security and agricultural sector sustainability. The objective of the research is to know the effect of social to career prospects on agricultural career empirically. The research involves 110 respondents with a questionnaire as a research instrument. The type of research in this study is survey research, the type of research which the way to collect data obtained or collected from the sample or population under study. Testing is done with a regression test to determine the effect of social status on career prospects in agriculture. The results of this study indicate that social status has an influence on perceptions of career prospects in the agricultural sector.
\end{abstract}

Keywords: career, social status, youth, agriculture 


\section{INTRODUCTION}

The role of Indonesian agricultural labor in national employment is undeniably the largest contribution, which is around $35.3 \%$ (Ministry of Agriculture, 2015). However, until now, there are still serious problems in the agricultural labor sector. The main problem is the change in the demographic structure that is not profitable for the agricultural sector, in which the number of older farmers (over 55 years) is increasing, while the number of young workers is decreasing. The phenomenon of the aging farmer and the declining interest of young workers in the agricultural sector adds to the classic problem of agricultural labor so far, which is the low average level of education compared to that of workers in other sectors.

The reasons for the decline of the interest of young workers in the agricultural sector are mainly because the image of the agricultural sector is less prestigious and unable to provide an adequate salary. This is rooted in the relatively narrow field mastery for the farming business. Another reason is that the perspectives and way of life of young workers have changed in the current development era of postmodern societies. For young people in rural areas, the agricultural sector is increasingly losing its attractiveness. Not only because the agricultural sector is becoming economically less promising, but the reluctance of young people to farm is actually also affected by the new subculture that is developing in the recent digital era. The crisis of young farmers in the agricultural sector and the dominance of old farmers has consequences for the development of the sustainable agricultural sector, especially on agricultural productivity, market competitiveness, rural economic capacity, and this will further threaten food security and the sustainability of the agricultural sector (Susilowati, 2016).

The agricultural sector is generally characterized by 3D, including dirty, dangerous, and difficult (Wang, 2014). With such perceptions, it will not be easy to attract young workers to the agricultural sector. For the availability of food, it is indeed necessary to sustain agricultural development. This agricultural development will continue if there are people who work in the agricultural sector and the regeneration of farmers is established. When there is farmer regeneration, there are automatically young farmers who continue to work in the agricultural sector with the input of technological innovations that continue to develop so that there are those who continue to work in the agricultural sector to produce food. However, if there is no farmer regeneration, it can cause a food crisis. In fact, the agricultural sector is a producer of various crops, livestock, and fisheries commodities. Since the beginning of human civilization around the world, it has been a major contributor to the supply of food.

The relationship between job status and career prospects is also supported by a study by Sandiford and Seymour (2010). They interviewed bar workers in the UK and found that the respondents perceived that working in a bar had a higher status than working in other jobs because it provided better career prospects in terms of better job content, more opportunities to work for positions they like, and better income. Zhao and Zhou (2008) analyzed career choice in Taiwan and also reported that the social status of work played an important role in shaping future career prospects because an individual perceives progress (i.e. through a promotion) and an individual's decisions about commitment or job changes. An individual who is aware of social and organizational interests and job needs usually makes a greater effort to meet job requirements and increases work productivity because of their positive perceptions of career prospects (Tittel, 1976). Other studies also acknowledged that external perceptions of prestige and social status lead to employees' affective commitment, citizenship behavior, and more importantly, their affective state at the workplace (Carmeli, 2005). Such prestige and social status illustrate a positive image to employees with 
reference to the organization or industry they are currently involved in.

The phenomenon of decreasing interest of young workers to work in the agricultural sector has consequences for the sustainability of the agricultural sector going forward. In the future, the burden on the agricultural sector will become heavier with an increase in population and an increase in demand for food so that an increase in production and productivity are the key factors. Students and young workers as the next generation of farmers must be encouraged to return to the agricultural sector and be responsible for increasing agricultural production and productivity and national food supply. This study aimed to determine the perceptions of youth, especially students of the Faculty of Agriculture, on social status and career prospects in the agricultural sector and the relationship between the two.

\section{RESEARCH METHODS}

This study was conducted at the campus of the Faculty of Agriculture, Universitas Gadjah Mada (UGM) Yogyakarta using a questionnaire. The population in this study were students of the Faculty of Agriculture of UGM starting from the fifth semester. The consideration is that they have had an overview of future jobs, including in the agricultural sector. The type of research used in this study was survey research, which is the type of research in which the data are obtained or collected from the sample or population studied. According to Cooper \& Schlinder (2014), a survey is a measurement process used to gather a higher level of information than structured interviews. This study was conducted with a quantitative approach. The sampling was carried out by means of simple random sampling involving 110 students covering all majors. Comrey (1973) stated that for various research purposes, if the subject is homogeneous and the number of variables studied is not many, a sample size between 100-200 is considered good. The sampling technique used the accidental sampling technique, where the sampling was not determined in advance but the researcher directly collected the data from the sampling unit found. Once the data collection was sufficient, the data collection was stopped. The data analysis was carried out using the correlation test. The statistical tests were carried out using the Statistical Package for Social Science (SPSS) 22.

\section{RESULTS AND DISCUSSION}

\section{Social Status in the Agricultural Sector}

Social status is measured by measuring instruments developed by the researcher based on previous research conducted by Jolodar (2011). Status is an individual's position that can be reviewed regardless of the individual themselves. The respondents' perceptions on the social status in the agricultural sector are presented in Table 1.

Based on Table 1, it obtained that the respondents' perception of the social status of agricultural careers was $69 \%$. The highest achievement was in statement number 6 (interaction with colleagues) with a percentage of $86.72 \%$ where the respondents looked more positively to relationships between colleagues in the agricultural sector because they are considered capable of giving respect to others, can easily solve problems with coworkers, have a good supervisor-subordinate relationship, and there is honesty. The lowest achievement was in statement number 5 (sense of job security) with a percentage of $57.27 \%$ because it is considered that the value of the position in the career process is not good when working in the agricultural sector.

The categorization of respondents' perceptions on the social status was carried out based on the normal distribution model. Furthermore, for the purposes of categorizing values, the standard score would be used, which is to convert the score into a deviation from the mean in standard deviation units (Azwar, 1999). The norms used in this categorization were three categories as follows. 
Table 1. Respondents' Perceptions on the Social Status in the Agricultural Sector

\begin{tabular}{|c|c|c|c|c|}
\hline No. & Indicator & $\begin{array}{l}\text { Interval } \\
\text { Score }\end{array}$ & $\begin{array}{c}\text { Average } \\
\text { Achievement } \\
\text { Score }\end{array}$ & $\begin{array}{l}\text { Level of } \\
\text { Role } \\
(\%)\end{array}$ \\
\hline 1. & $\begin{array}{l}\text { I will obtain good welfare and social status if } \\
\text { I work in the agricultural sector. }\end{array}$ & $1-5$ & 3.26 & 65.27 \\
\hline 2. & $\begin{array}{l}\text { Jobs in the agricultural sector are prestigious } \\
\text { jobs. }\end{array}$ & $1-5$ & 3.61 & 72.36 \\
\hline 3. & $\begin{array}{l}\text { I will earn a proper salary and benefits } \\
\text { working in the agricultural sector. }\end{array}$ & $1-5$ & 3.01 & 60.36 \\
\hline 4. & $\begin{array}{l}\text { Working in agriculture benefits less than that } \\
\text { in other fields. }\end{array}$ & $1-5$ & 2.81 & 56.36 \\
\hline 5. & $\begin{array}{l}\text { I will obtain a suitable position if I work in } \\
\text { the agricultural sector. }\end{array}$ & $1-5$ & 2.86 & 57.27 \\
\hline 6. & $\begin{array}{l}\text { I will perceive respect in the workplace if I } \\
\text { work in the agricultural sector. }\end{array}$ & $1-5$ & 4.33 & 86.72 \\
\hline \multirow[t]{2}{*}{7.} & $\begin{array}{l}\text { I will perceive a good supervisor-subordinate } \\
\text { job relationship if I work in the agricultural } \\
\text { sector. }\end{array}$ & $1-5$ & 4.2 & 84 \\
\hline & Total & & 3.44 & 69 \\
\hline
\end{tabular}

Source: Primary Data, 2018

$\begin{array}{ll}\mathrm{X}>\mathrm{Mi}+\mathrm{Sb} & : \text { Good } \\ \mathrm{Mi}-\mathrm{Sb} \leq \mathrm{X} \leq \mathrm{Mi}+\mathrm{Sb} & : \text { Average } \\ \mathrm{X}<\mathrm{Mi}-\mathrm{Sb} & : \text { Deficient }\end{array}$

Based on the norms that have been determined above, the norms that would be used as guidelines for categorizing the perception values on the social status in the agricultural sector are shown in Table 2 below.
Based on the value categories above, the empirical data analyzed using the subjective norms of the research subject can be elaborated as follows.

The results of the study showed that the subjects who had a good perception of the social status in the agricultural sector were 14 (12.7\%) people, 81 (73.6\%) people in the moderate category, and $15(13.6 \%)$ people in the category.

Table 2. The Norms of Perception Values on the Social Status in the Agricultural Sector

\begin{tabular}{cc}
\hline The Value of $\mathrm{X}$ & Information \\
\hline $28,509<\mathrm{X}$ & Good \\
$28,509 \geq \mathrm{X} \geq 19,931$ & Average \\
$\mathrm{X}<19,931$ & Deficient \\
\hline
\end{tabular}

Source: Primary Data, 2018

Tabel 3. Social Status Variable Categorization

\begin{tabular}{ccc}
\hline Category & Frequency & Percentage (\%) \\
\hline Good & 14 & 12,7 \\
Average & 81 & 73,6 \\
Deficient & 15 & 13,6 \\
\hline
\end{tabular}

Source: Primary Data, 2018 
Kibirige et al. (2017), in their findings, revealed that socio-economic characteristics including gender, years of experience in farming, land ownership, parents' job, and sources of income are factors that significantly affect youth perceptions of careers in the agricultural sector. The average score showed that youth had negative perceptions of agriculture with little interest due to lack of knowledge and low attractiveness of the agricultural industry.

\section{Career Prospects in the Agricultural Sector}

Career prospects were measured by measuring instruments developed by the researcher based on a previous study by $\mathrm{Mc}$ Graw (2011), Herren, et al. (2011), and Wildman and Torres (2002). The respondents' perceptions on the career prospects in the agricultural sector are presented in Table 4 .

Based on Table 4, it is found that the respondents' perception of the career prospects in the agricultural sector was $69.2 \%$. The highest achievement was in statement number 2 (salary and benefits) with a percentage of $72.4 \%$. This shows that salary is still a matter of great concern to respondents in career selection decisions. The lowest achievement was in statement number 4 (family, friends, and alumni) with a percentage of $56.4 \%$. This shows that family, friends, and alumni have less effect on respondents' consideration of career choices.

The categorization of respondents' perceptions of the career prospects in the agricultural sector was carried out based on the normal distribution model. Furthermore, for the purposes of categorizing values, the standard score would be used, which is to convert the score into a deviation from the mean in standard deviation units (Azwar, 1999). The norms used in this categorization were three categories as follows.
$\mathrm{X}>\mathrm{Mi}+\mathrm{Sb} \quad:$ Good
$\mathrm{Mi}-\mathrm{Sb} \leq \mathrm{X} \leq \mathrm{Mi}+\mathrm{Sb} \quad$ : Average
$\mathrm{X}<\mathrm{Mi}-\mathrm{Sb}$
: Deficient

Based on the norms that have been determined above, the norms that would be used as guidelines for categorizing the perception values on the career prospects in the agricultural sector are shown in Table 5.

Tabel 4. Respondents' Perceptions on the Career Prospects in the Agricultural Sector

\begin{tabular}{|c|c|c|c|c|}
\hline No. & Indicator & $\begin{array}{l}\text { Interval } \\
\text { Score }\end{array}$ & $\begin{array}{l}\text { Average } \\
\text { Achievement } \\
\text { Score }\end{array}$ & $\begin{array}{l}\text { Level of Role } \\
\qquad(\%)\end{array}$ \\
\hline 1. & $\begin{array}{l}\text { I will have few job promotion } \\
\text { opportunities if I work in the } \\
\text { agricultural sector. }\end{array}$ & $1-5$ & 2.74 & 54.7 \\
\hline 2. & $\begin{array}{l}\text { I will earn a proper salary and benefits } \\
\text { working in the agricultural sector. }\end{array}$ & $1-5$ & 3.62 & 72.4 \\
\hline 3. & $\begin{array}{l}\text { Working in the agricultural sector is an } \\
\text { unsuitable work environment for me. }\end{array}$ & $1-5$ & 2.92 & 58.9 \\
\hline 4. & $\begin{array}{l}\text { Many of my family and friends work in } \\
\text { the agricultural sector. }\end{array}$ & $1-5$ & 2.82 & 56.4 \\
\hline 5. & $\begin{array}{l}\text { I don't have any experience working in } \\
\text { the agricultural sector. }\end{array}$ & $1-5$ & 3.14 & 62.7 \\
\hline 6. & $\begin{array}{l}\text { I have many contacts who work in the } \\
\text { agricultural sector. }\end{array}$ & $1-5$ & 3.28 & 65.6 \\
\hline \multicolumn{3}{|c|}{ Total } & 2.96 & 59.2 \\
\hline
\end{tabular}

Source: Primary Data, 2018 
Table 5. The Norms of Perception Values on the Career Prospects in the Agricultural Sector

\begin{tabular}{cc}
\hline The Value of $X$ & Information \\
\hline $22,481<\mathrm{X}$ & Good \\
$22,481 \geq \mathrm{X} \geq 15,239$ & Average \\
$\mathrm{X}<15,239$ & Deficient \\
\hline
\end{tabular}

Source: Primary Data, 2018

Based on the value categories above, the empirical data analyzed using the subjective norms of the research subject can be elaborated as follows.

The results of the study showed that the subjects who had a good perception of the career prospects in the agricultural sector were $15(13.6 \%)$ people, $79(71.8 \%)$ people in the moderate category, and $16(14.5 \%)$ people in the poor category. Based on a study by Tapanapunnitikul and Prasunpangsri (2014), most younger generations from farming families do not want to be farmers. In their perception, working in the agricultural sector requires hard work, but the income is small, so they will not be rich. The conditions of poverty they experience do not make them interested in continuing a career in the agricultural sector and they move to the nonagricultural sector. Another obstacle that discourages young people from farming is the high cost of production while there is no the influence of weather which results in high yield losses.

\section{The Relationship between Social Status and} Career Prospects in the Agricultural Sector

Testing the relationship between social status in the agricultural sector and career prospects in the agricultural sector was carried out using linear regression analysis. The results of the research analysis are shown in the table below.

Based on Table 7 above, it shows that the social status variable in the agricultural sector was significant $(\mathrm{p}<0.05)$, with $\mathrm{t}$-count $=4.690$ with a positive relationship direction. This means that there is a significant effect between social status on perceptions of career prospects in the agricultural sector. Therefore, the results of this study can create a regression equation.

$$
Y^{\prime}=10,452+0,347 X_{1}
$$

Table 6. Career Prospect Variable Categorization

\begin{tabular}{ccc}
\hline Category & Frequency & Percentage \\
\hline Good & 15 & $13,6 \%$ \\
Average & 79 & $71,8 \%$ \\
Deficient & 16 & $14,5 \%$ \\
\hline
\end{tabular}

Source: Primary Data, 2018

Table 7. Linear Regression Analysis

\begin{tabular}{ccc}
\hline No & Analysis & Value \\
\hline 1. & Koefisien Regresi (B) & 0,347 \\
2. & Konstanta & 10,452 \\
3. & T hitung & 4,690 \\
4. & Sig & 0,000 \\
\hline
\end{tabular}

Source: Primary Data, 2018 
Table 8. The Results of the Analysis of the Aspects of the Social Status Variable

\begin{tabular}{lcccc}
\hline \multicolumn{1}{c}{ Aspects } & F Value & $\mathrm{P}$ & Contribution & Information \\
\hline Personnels belief & 4,227 & 0,017 & $7,3 \%$ & Signifikan \\
Salary and benefits & 18,651 & 0,000 & $25,9 \%$ & Signifikan \\
Sense of job security & 12,334 & 0,001 & $10,2 \%$ & Signifikan \\
Interaction with & 5,096 & 0,008 & $8,7 \%$ & Signifikan \\
colleagues & & & & \\
\hline
\end{tabular}

Source: Primary Data, 2018

Thus, if the value of B is constant, the average value of the perception of social status is 10.452 . Based on the above equation, it also obtained that the regression coefficient was positive, meaning that there was an effect that was directly proportional to the social status variable with the perception of career prospects in the agricultural sector. This means that every one unit increase in the social status variable in the agricultural sector will cause an increase in the perception of career prospects in the agricultural sector by 0.347 . To increase the public awareness to agricultural sector Prayoga et al. (2020) said that massive socialization is needed to increase public understanding and interest.

In detail, based on its aspects, the results of the analysis of the aspects of the social status variable can be seen in Table 8 below.

From the four aspects of social status, it is obtained that all aspects of social status affected the perception of career prospects in the agricultural sector. The highest effect of these four aspects was the aspect of salary and benefits, while the aspect that had the smallest contribution was the personnels belief.

\section{CONCLUSIONS}

The results of this study showed that there was a significant effect of the social status in the agricultural sector on the perception of career prospects in the agricultural sector. Based on the results of the regression analysis calculation, it showed that there was a significant effect and had a positive direction between social status and career prospects in the agricultural sector. The current job characteristics and social status of the agricultural sector are generally perceived to be inferior, affecting the career prospects of the agricultural sector. Therefore, this becomes a challenge for stakeholders to develop the agriculture and food sector.

\section{REFERENCES}

Azwar, S. 1999. Penyusunan Skala Psikologi. Yoyakarta: Pustaka Pelajar.

Comrey, A. L. 1973. First Cource in Factor Analysis. New York. Academic Press.

Kibirige, D., A. S. Singh and Zvenyika K. R. 2017. Perceptions of Swaziland's youth towards farming: A case of Manzini Region. Forestry Research and Engineering: International Journal 1(3): 83-89.

Herren C. D., D. D. Cartmell and J. T. Robertson. 2011. Perceptions of influence on college choice by students enrolled in a college of agricultural sciences and natural resources. NACTA Journal 55(3): 54-60.

Jolodar, S. 2012. An investigation of social factor affecting on personnel job satisfaction of remedial service insurance department. Iranian Journal of Management Studies 5(1): 97-110.

Kementerian Pertanian. 2015. Rencana strategis Kementerian Pertanian Tahun 2015-2019. Jakarta: Kementerian Pertanian. 
McGraw, K., J. S. Popp, B. L. Dixon and D. J. Newton. 2012. Factors influencing job choice among agricultural economics professionals. Journal of Agriculture and Applied Economics 44(2): 251265.

Prayoga, K., S. Nurfadillah, and A. M. Riezky. 2020. Penguatan sistem pendidikan SDM dalam pembangunan pertanian: agribisnis di mata pemuda. Jurnal Agrisep 19(1): 53-67.

Susilowati, S. H. 2016. Fenomena penuaan petani dan berkurangnya tenaga kerja muda serta implikasinya bagi kebijakan pembangunan pertanian. Forum Peneliti Agro Ekonomi 34(1): 35-55.

Tapanapunnitikul, O. and S. Prasunpangsri. 2014. Entry of young generation into farming in Thailand. FFTC-RDA 2014 International Seminar on Enhanced Entry of Young Generation into Farming. Korea. Jeonju.

Wang, J. H. 2014. Recruiting young farmers to join smallscale farming: a structural policy perspective. FFTC-RDA 2014 International Seminar on Enhanced Entry of Young Generation into Farming. Korea. Jeonju.

Wildman, M. L. and R. M. Torres. 2002. Factors influencing choice of major in agriculture. NACTA Journal 46(3): 49. 